\section{Avaliação do comportamento e das atitudes dos portadores de HIV, doentes ou não: comparação entre indivíduos adultos do sexo masculino e feminino}

\begin{abstract}
A AIDS danifica o sistema imunológico e leva
\end{abstract} a doenças oportunistas e neoplasias malígnas que se tornam causa direta de morte. Como, até o momento, não há tratamento definitivo para a doença, a abordagem principal é sua prevenção, visando a diminuir o risco da infecção pela ação educativa, o que possibilita a redução da infecção pelo HIV e o controle da sua propagação. Mas, para isto, a população de portadores deve ser bem caracterizada, respeitando-se as diferenças existentes em cada região e, ainda, entre os dois sexos envolvidos. A pesquisa teve como objetivos verificar o conhecimento e as atitudes dos portadores do HIV em relação à sua condição, bem como a diferença entre os sexos e a reação dos indivíduos do seu relacionamento a esta condição. Neste estudo, encontrou-se razão homem:mulher de 1,6:1, resultado semelhante ao observado em todo o mundo, isto é, uma crescente diminuição na proporção homem:mulher. Os portadores do sexo masculino eram mais velhos que as portadoras, sendo que a maioria deles era de solteiros, situação oposta à das portadoras. Entre as mulheres, $70 \%$ tinham apenas nível elementar, e a maioria dos homens tinha escolaridade igual ou superior ao $2^{\circ}$ grau. Mais da metade das mulheres era donas de casa, enquanto que, entre os homens, predominavam as ocupações que requeriam alguma qualificação. A via sexual foi a principal veiculadora do vírus, homo/bissexual para os homens e heterossexual, para as mulheres. Houve predomínio, nos dois sexos, de indivíduos apresentando, já, sinais e sintomas da doença no momento da entrevista. Após o diagnóstico, os familiares se afastaram com maior freqüência das mulheres, talvez indício de que, entre nós, os homens sejam melhor entendidos pela família. As mulheres tiveram maior dificuldade em contar seu diagnóstico para os parceiros e, quando isso ocorreu, houve maior afastamento deles, do que delas, em relação a

\author{
Comparison of \\ the behavior and \\ attitudes of HIV-infected \\ men and women \\ with or without \\ AIDS
}

AIDS impairs the immunological system and leads to opportunistic infections and malignant neoplasias which become a direct cause of death. Since, for the time being, there is no definite treatment for HIV disease, the main approach is prevention, aiming to decrease infection risks through education actions which permit a reduction of HIV infection and the control of its spread. However, the carrier population should be well characterized and regional and sex differences should be taken into account. The objective od the present study was tot verify the knowledge and attitudes toward their condition of HIV carriers, as well as the differences between sexes and reactions of other individuals to this condition. In the present study, a 1.6:1 man: woman ratio was found, a similar result observed throughout the world, i.e., a high decrease in the man:woman ratio. Male carriers were single and older than female carriers (who were in the opposite situation). Among women, $70 \%$ had elementary education, whereas most men had high school or higher education. Half or more women were housewives while among men skilled jobs prevailed. Sexual contact (homosexual/heterosexual for men, and heterosexual for women) was the main pathway of virus transmission. In both sexes, there was a prevalence of some individuals who presented HIV symptoms at the time of the interview. After diagnosis, family members abandoned women more often, indicating that men are better supported by their family. Women found it difficult to reveal their diagnosis to their sexual partners and when they did, they were abandoned by their male partners more often than in the opposite situation, i.e., when male partners revealed their infection. A significant number of carriers looked for support from several religions; however, $36.6 \%$ of men and $42.0 \%$ of women stated that after diagnosis they no longer engaged in social

Recebido para publicação em 12/3/99. 
companheiros que se confessaram infectados. Parcela significativa de indivíduos portadores, de ambos os sexos, procurou apoio em diferentes religiões, mas $36,6 \%$ dos homens e $42 \%$ das mulheres referiram que, após o diagnóstico, deixaram de participar de atividades sociais. Não continuaram trabalhando $42,7 \%$ dos homens e $40 \%$ das mulheres, após o diagnóstico. A falta de adesão ao acompanhamento médico foi encontrada em $17,1 \%$ dos homens e $8 \%$ das mulheres e, procuraram por terapia alternativa, $19,0 \%$ dos indivíduos da casuística. Como medida para evitar o contágio, mantiveram abstinência sexual $58,5 \%$ dos homens e $56,0 \%$ das mulheres e o uso de preservativo, medida mais divulgada, não foi utilizado por $24 \%$ dos homens e $30 \%$ das mulheres. Para controlar a evolução da doença $44 \%$ das mulheres e $25,6 \%$ dos homens nada faziam. Referiram conhecimento suficiente sobre os meios de transmissão da doença $69,5 \%$ dos portadores masculinos. Mais de $50 \%$ das mulheres referiram conhecimento insuficiente. Muito grave, por se tratar de infecção que leva à morte, foi a citação, por 10,9\% dos portadores e $38 \%$ das portadoras, de que nada faziam para impedir a transmissão a outros indivíduos. A maior porcentagem de indivíduos que não revelaram seu estado de portador do HIV para seus parceiros, ou parceiras, sexuais foi encontrada entre homens, explicando de certa forma, o grande número de mulheres infectadas por esta via. As mulheres se abstiveram mais de contar, a médicos e dentistas consultados, seu estado de portadoras, enquanto que os homens revelaram sua condição menos freqüentemente ao dentista. A análise dos resultados permitiu concluir, quanto às características da casuística, que houve pior desempenho das mulheres que eram mais jovens, tinham menor escolaridade e pior qualificação profissional e foram infectadas pela via heterossexual, sendo que, cerca de $1 / 3$ delas, pelos próprios maridos. Quanto à caracterização das perguntas dirigidas, as mulheres tiveram pior desempenho em relação às condições de infecção e à repercussão social desta infecção. Apesar disso, assumiram atitudes mais positivas diante de sua situação do que os homens, comunicando sua condição de infectada aos familiares, seguindo tratamento convencional e procurando menos por terapias alternativas. activities; $42.7 \%$ of men and $40 \%$ of women stopped working after diagnosis; $17.1 \%$ of men and $8 \%$ of women did not comply with treatment and $19 \%$ of individuals looked for alternative therapy. As means to avoid transmission, $58.5 \%$ men and $56 \%$ women abstained from sexual intercourse, and $24 \%$ of men and $30 \%$ of women did not use a condom (the protection most frequently advertised in the media). Nothing was done to control the course of the disease growth by $44 \%$ of women and $25.6 \%$ of men. Sufficient knowledge concerning HIV disease transmission was reported by $69.5 \%$ of men carriers, whereas $50 \%$ of women reported insufficient knowledge. Men carriers $(10.9 \%)$ and women carriers (38\%) stated that they did not do anything to avoid transmission to other individuals, a very serious matter when one is dealing with a lethal disease. The highest percentage of individuals who did not reveal their HIV carrier status to their male or female partners were found among men, explaining somehow the large number of women infected through this way. Women refrained more from stating their carrier status to doctors and dentists, while men revealed their condition less often to dentists. We conclude that, with respect to the characteristics of this series, the worst performance was found among unskilled young women with low education, onethird of them infected heterosexually by their own husbands. With respect to directed questions, women showed the worst performance in terms of contamination conditions and social reaction to the infection. However, women had more positive attitudes than men, informing their family about their health condition, following conventional treatment and searching less for alternative therapies.

\section{Marli Teresinha Gimeniz Galvão}

Tese apresentada à Faculdade de Medicina de

Botucatu da Universidade Estadual Paulista para obtenção do Título de Mestre.

Botucatu, SP, Brasil, 1998. 